\title{
Pengaruh Kompensasi, Gaya Kepemimpinan dan Motivasi Kerja Terhadap Kinerja Pegawai pada Badan Arsip dan Perpustakaan Provinsi Aceh
}

\author{
Sarboini ${ }^{1}$, Mariati ${ }^{2}$ \\ ${ }^{1}$ Dosen Fakultas Ekonomi dan Bisnis Islam, Universitas \\ Serambi Mekkah, Banda Aceh \\ ${ }^{2}$ Dosen Fakultas FKIP, Universitas Serambi Mekkah, Banda \\ Aceh
}

\begin{abstract}
Abstrak. Penelitian ini bertujuan untuk mengetahui pengaruh kompensasi, Gaya Kepemimpinan dan motivasi kerja terhadap kinerja pegawai pada Badan Arsip Dan Perpustakaan Provinsi Aceh. Penelitian ini di laksanakan pada Badan Arsip Dan Perpustakaan Provinsi Aceh, dengan objek penelitian adalah tentang pengaruh kompensasi, Gaya Kepemimpinan dan motivasi kerja terhadap kinerja pegawai pada Badan Arsip dan Perpustakaan Provinsi Aceh. Analisis ini berdasarkan atas data yang diperoleh dari 181 orang populasi penentuan sampel dalam penelitian ini dengan menggunakan rumus Slovin, yaitu sebanyak 44 orang sampel. Dalam penelitian ini metode analisis data yang di gunakan adalah metode analisis regresi linear berganda (Multiple Linear Regression) yang diolah dengan program SPSS (Statistical Product and Service Solution). Hasil penelitian berdasarkan uji F (secara simultan) di peroleh Fhitung sebesar 24,196 sedangkan Ftabel pada tingkat signifikan $a=5 \%$ adalah 3,225. Hal ini memperlihatkan bahwa Fbitung > Ftabel, dengan tingkat signifikansi 0.000. Hasil perbitungan ini dapat diambil suatu kesimpulan babwa menerima hipotesis nol, artinya bahwa variabel kompensasi (X1) gaya kepemimpinan (X2) dan motivasi kerja (X3), secara bersama-sama berpengaruh secara signifikan terbadap kinerja pegawai pada Badan Arsip Dan Perpustakaan Provinsi Aceh. Artinya secara keseluruban responden menyatakan setuju terhadap indikatoryang di teliti, dengan demikian mempengarubi kinerja pegawai pada Badan Arsip Dan Perpustakaan Provinsi Aceh. Sedangkan secara parsial dari tiga variabel yang di teliti, ternyata variabel kompensasi (X1) yang mempunyai pengaruh dominan terhadap kinerja pegawai pada Badan Arsip Dan Perpustakaan Provinsi Aceh, karena di peroleh nilai koefisien regresi lebih besar di bandingkan dengan variabel lainnya.
\end{abstract}

Kata kunci: kompensasi, gaya kepemimpinan, motivasi kerja, kinerja pegawai.

\begin{abstract}
This study aims to determine the effect of compensation, leadership style and work motivation on employee performance in the Archives and Library of Aceh Province. This research was conducted at the Archive and Library Agency of the Province of Aceh, with the object of research being the effect of compensation, Leadership Style and work motivation on employee performance at the Archive and Library Board of the Province of Aceh. This analysis is based on data obtained from 181 population determination of the sample in this study using the Slovin formula, which is 44 people sampled. In this study, the data analysis method used is multiple linear regression analysis methods (Multiple Linear Regression) which are processed with the SPSS (Statistical Product and Service Solution) program. The results of the study based on the F test (simultaneously) obtained an F-count of 24.196 while the Ftable at a significant level a $=5 \%$ was 3.225. This shows that Fcount $>$ F table, with a significance level of 0,000. The results of this calculation can be drawn a conclusion that accepting the null bypothesis, meaning that the compensation variable (X1) leadership style (X2) and work motivation (X3), jointly have a significant effect on employee performance at the Aceh Provincial Archives and Library Board. This means that overall respondents agreed to the indicators examined, thereby affecting the performance of employees at the Aceh Provincial Archives and Library Board. While partially from the three variables examined, it turns out that the compensation variable (X1) which has a dominant influence on employee performance at the Aceh Provincial Archives and Library. Agency, because the regression coefficient is greater than the other variables.
\end{abstract}

Keywords: compensation, leadership style, work motivation, employee performance.

*Corresponding author. Email: sarboinise@serambimekkah.ac.id ${ }^{1}$

DOI: https://doi.org/10.35870/emt.v4i1.124

Received: 2 January 2020, Revision: 11 Februari 2020, Accepted: 20 April 2020

Print ISSN: 2579-7972; Online ISSN: 2549-6204.

Copyright@ 2020. Published by Lembaga Otonom Lembaga Informasi dan Riset Indonesia (KITA INFO dan RISET). 


\section{Pendahuluan}

Sumber daya manusia merupakan tokoh sentral dalam organisasi maupun perusahaan agar aktivitas manajemen berjalan dengan baik (Handayati, 2016), instansi harus memiliki pegawai yang berpengetahuan dan berketerampilan tinggi serta usaha meningkat (Akmal, Lubis, Yunus, 2012), kinerja yang baik adalah kinerja yang optimal, yaitu kinerja yang sesuai standar organisasi dan mendukung tercapainya tujuan organisasi (Brahmasari, Suprayetno, 2008), organisasi yang baik adalah organisasi yang berusaha meningkatkan kemampuan sumber daya manusianya (Tampubolon, 2007), karena hal tersebut merupakan faktor kunci untuk meningkatkan kinerja pegawai (Tampubolon, 2007; Widayaningtyas, 2016).

Kompensasi sangatlah penting karena merupakan dorongan utama seseorang untuk bekerja (Firmandari, 2014), tetapi masalah kompensasi yang diberikan oleh instansi kepada pegawainya mempunyai pengaruh yang tinggi terhadap moral, disiplin dan prestasi kerja. Oleh karena itu, instansi atau organisasi manapun sebaiknya dapat menetapkan kompensasi yang seimbang dengan beban kerja yang diterima oleh pegawainya, sehingga dapat menjamin terwujudnya tujuan pembinaan pegawai dan tujuan instansi untuk meningkatkan pendapatan dan pelayanan (Akny, 2014; Aulia Maya, 2020). Gaya kepemimpinan merupakan norma perilaku yang digunakan oleh seseorang pada saat orang tersebut mencoba mempengaruhi perilaku orang lain (Antou, 2013; Maria, 2012), gaya kepemimpinan cocok apabila tujuan perusahaan telah dikomunikasikan dan bawahan telah menerimanya (Reza dan Dirgantara, 2010), seorang pemimpin harus menerapkan gaya kepemimpinannya untuk mengelola bawahannya karena seorang pemimpin akan sangat mempengaruhi keberhasilan organisasi dalam mencapai tujuan (Tampi, 2014).

Motivasi adalah dorongan, upaya dan keinginan yang ada didalam diri manusia yang mengaktifkan, memberi daya serta mengarahkan perilaku untuk melaksanakan tugas-tugas dengan baik dalam lingkup pekerjaannya (Salutondok dan Soegoto, 2015;
Nitasari dan Lataruva, 2012), instansi menggunakan penghargaan atau hadiah dan ketertiban sebagai alat untuk memotivasi pegawai, pemimpin mendengarkan ide-ide dari para bawahannya sebelum mengambil keputusan (Nuraini dan Miswanta, 2016). Gaya kepemimpinan yang tepat akan menimbulkan motivasi seseorang untuk berprestasi sukses tidaknya pegawai dalam prestasi kerja dapat dipengaruhi oleh gaya kepemimpinan (Tampubolon, 2007; Widodo, 2006). Terdapat faktor negatif yang dapat menurunkan kinerja pegawai (Susanty dan Baskoro, 2012), diantaranya adalah menurunnya keinginan pegawai untuk mencapai prestasi kerja, kurangnya ketetapan waktu dalam penyelesaian pekerjaan sehingga kurang mentaati (Akmal, Lubis, Yunus, 2012).

Perumusan penelitian adalah 1) Apakah kompensasi berpengaruh terhadap kinerja pegawai pada Badan Arsip Dan Perpustakaan Provinsi Aceh, 2) Apakah gaya kepemimpinan berpengaruh terhadap kinerja pegawai pada Badan Arsip Dan Perpustakaan Provinsi Aceh, 3) Apakah motivasi kerja berpengaruh terhadap kinerja pegawai pada Badan Arsip Dan Perpustakaan Provinsi Aceh, dan 4) Apakah kompensasi, gaya kepemimpinan dan motivasi kerja berpengaruh secara simultan terhadap kinerja pegawai pada Badan Arsip Dan Perpustakaan Provinsi Aceh. Sedangkan yang menjadi tujuan penelitian adalah; 1) Untuk mengetahui besarnya pengaruh kompensasi terhadap kinerja pegawai pada Badan Arsip Dan Perpustakaan Provinsi Aceh, 2) Untuk mengetahui pengaruh gaya kepemimpinan terhadap kinerja pegawai pada Badan Arsip Dan Perpustakaan Provinsi Aceh, 3) Untuk mengetahui pengaruh motivasi kerja, terhadap kinerja pegawai pada Badan Arsip Dan Perpustakaan Provinsi Aceh, dan 4) Untuk mengetahui pengaruh kompensasi, gaya kepemimpinan, dan motivasi kerja terhadap kinerja pada Badan Arsip Dan Perpustakaan Provinsi Aceh.

\section{Literature Review}

\section{Kompensasi}

Kompensasi merupakan pengeluaran dan biaya bagi instansi. Instansi mengharapkan agar kompensasi yang di bayarkan memperoleh 
imbalan prestasi kerja yang lebih besar dari kompensasi yang dibayar instansi, supaya instansi mendapat laba dan kontinuitas perusahaan terjamin Hasibuan (2001). Hasibuan (2001) juga menyatakan bahwa kompensasi adalah semua pendapatan yang berbentuk uang, barang langsung atau tidak langsung yang diterima karyawan sebagai imbalan atas jasa yang diberikan kepada instansi. Sedangkan menurut Nitisemito (2001) " kompensasi adalah merupakan balas jasa yang diberikan oleh perusahaan kepada karyawan yang dapat dinilai dengan uang dan mempunyai kecendrungan yang diberikan secara tetap".

Menurut Handoko (2001) kompensasi adalah segala sesuatu yang diterima para karyawan sebagai balas jasa untuk kerja mereka. Sementara Rivai (2004) menyatakan bahwa kompensasi merupakan sesuatu yang diterima karyawan sebagai pengganti kontribusi jasa mereka pada perusahaan. Panggabean (2002) kompensasi merupakan segala bentuk penghargaan (outcomes) yang diberikan kepada organisasi. Menurut Hariandja (2002) komepnsasi adalah keseluruhan balas jasa yang diterima oleh pegawai sebagai akibat dari pelaksanaan pekerjaan di organisasi dalam bentuk uang atau lainnya.

\section{Gaya Kepemimpinan}

Kepemimpinan merupakan tulang punggung pengembangan organisasi karena tanpa kepemimpinan yang baik akan sulit mencapai tujuan organisasi, jika seseorang pemimpin berusaha untuk mempengaruhi perilaku orang lain maka orang tersebut perlu memikirkan gaya kepemimpinannya. Sadili dan Samsudin (2006) mendefinisikan sebagai berikut kepemimpinan adalah kemampuan meyakinkan dan kepemimpinan menggerakkan orang lain agar mau bekerja sama di bawah kepemimpinannya sebagai suatu tim untuk mencapai suatu tujuan tertentu. Selanjutnya Sihotang (2007) mendefenisikan kepemimpinan adalah keseluruhan aktivitas dalam rangka mempengaruhi orang-orang agar mau bekerja sama untuk mencapai tujuan yang memang dikehendaki bersama.

Sedangkan Rivai (2003) gaya kepemimpinan adalah sekumpulan ciri yang di gunakan pimpinan untuk mempengaruhi bawahan agar sasaran organisasi tercapai atau dapat di katakan bahwa gaya kepemimpinan adalah pola perilaku dan strategi yang di sukai dan sering di terapkan oleh seorang pemimpin. Mary coulter (2004) merumuskan kepemimpinan sebagai proses pengaruh dimana individi-individu, melalui tindakan mereka, mempermudah gerak suatu kelompok kearah sasaran umum atau sasaran bersama. Dari definisi di atas dapat di simpulkan bahwa kepemimpinan "adanya orang yang harus di pengaruhi (pengikut/bawahan), adanya orang mempengaruhi (pemimpin), adanya proses pencapaian tujuan. Setiap kepemimpinan haruslah mempunyai kekuatan, kekuatan yang di maksud adalah kemampuan seseorang dalam mempengaruhi orang lain. Jadi, seorang pemimpin harus memiliki kemampuan untuk membangkitkan kekuatan-kekuatan emosional yang rasional dari para pengkutnya, sehingga mereka antusias melaksanakan tugas-tugasnya. Dari beberapa definisi di atas maka dapat di simpulkan bahwa seorang pemimpin haruslah mempunyai kecakapan, keuletan, pengalaman serta kekuatan dan pengalaman yang sangat di perlukan untuk menggerakkan dan mempengaruhi bawahan.

\section{Motivasi Kerja}

Motivasi seringkali diistilahkan sebagai dorongan atau tenaga tersebut merupakan gerak jiwa dan jasmani untuk berbuat sehingga motif tersebut merupakan driving force yang mengerakan manusia untuk bertingkah laku dan di dalam perbuatannya itu mempunyai tujuan tertentu. As'ad (2001). Motivasi secara sederhana dapat di artikan 'motivating' yang secara implicit berarti bahwa pimpinan suatu organisasi berada di tengah-tengah bawahannya dengan demikian dapat memberikan bimbingan, intruksi, nasihat dan koreksi jika di perlukan. Sedangkan pendapat lain mengatakan bahwa motivasi adalah keinginan yang terdapat pada seorang individu yang merangsang untuk melakukan tindakan Winardi (2002). Motivasi adalah dorongan yang ada dalam diri manusia yang menyebabkan ia melakukan sesuatu Wursanto (2005). Dari berbagai pendapat diatas dapat di simpulkan yaitu motivasi merupakan dorongan/daya yang timbul dari diri, tanpa ada paksaan dari siapapun untuk melakukan suatu pekerjaan. 
Dengan kata lain, motivasi kerja adalah kemauan adalah kemauan seorang bawahan untuk mengerakan kemauan, keahlian dan keterampilannya dalam bekerja, karyawan dengan motivasi kerja yang tinggi akan bekerja secara maksimal.

\section{Kinerja}

Kinerja merupakan hasil pekerjaan yang mempunyai hubungan erat dengan tujuan strategi organisasi, kepuasan konsumen, dan memberikan kontribusi pada ekonomi Armstrong (2005). Sedangkan Robbins (2006) kinerja merupakan hasil kerja yang dihasilkan seorang pekerja untuk mencapai hasil yang baik. Kinerja merupakan tindakan sejauh mana anggota organisasi melaksanakan semua tugas pokoknya untuk mencapai semua sasaran. Sedangkan Siswanto (2002) mengemukakan kinerja adalah sampai beberapa jauh pengusaha melibatkan diri, menyumbang pikiran, tenaga, minat, dan pengorbanan untuk mendukung pelaksanaan operasional perusahaan dalam menghasilkkan output, dan jeri payah yang dilaksanakan pengusaha akan mendapatkan imbalan jasa. Dari hasil berbagai referensi maka jelas kinerja dapat dilihat dan diukur dari berbagai sudut jika dihubungkan dengan pengertian prestasi yang diperlihatkan. Selanjutnya Dahlan (2004). Mengatakan bahwa prestasi adalah suatu tinggkatan dimana seseorang mampu memenuhi harapan yang berhubungan dengan fungsinya atau gambaran reaksi dan pekerjaan. Oleh karena itu harapan yang ingin dicapai seseorang berkaitan dengan cara yang akan dimainkan seseorang tersebut sesuai dengan peran dalam.

\section{Faktor yang Mempengaruhi Kinerja}

Kinerja merupakan salah satu gambaran diri seorang pegawai dengan berbagai standar tugas yang telah diberikan kepada pegawai tersebut sebagai salah satu tanggung jawab. Kinerja (performace) ini cenderung dipengaruhi oleh berbagai faktor yaitu Menurut Manullang (2003), ada beberapa faktor yang mempengaruhi kinerja yaitu:

1. Pendidikan

Kemampuan seseorang dapat dilihat dari keahlian yang dimilikinya, keahlian tersebut dipengaruhi oleh latar belakang pendidikan dan pengalaman. Belajar adalah perubahan yang relatif permanen dalam pengetahuan, keahlian, kenyakinan, sikap prilaku yang dihasilkan oleh pengalaman.

2. Disiplin Kerja

Disiplin kerja dapat diartikan sebagai pelaksana manajemen untuk memperteguh pedoman-pedoman organisasi. Aspek penting didalam kelancaran suatu perkerjaan adalah factor disiplin yang mengikat semua karyawan untuk bekerja sesuai dengan aturan format yang disetujui bersama dapat melaksanakan pekerjaan dengan efektif dan efisisen. Disiplin kerja yang baik akan mendorong semua pegawai bekerja sesuai dengan tanggung jawab masing-masing sehingga hasil kerja yang dicapai akan maksimal.

3. Kesejahteraan

Adapun yang dimaksud dengan kesejahteraan adalah upah dan semua jenis tunjangan intensif, atau kompentasi yang diterima oleh pegawai sebagai ganjaran atas pekerjaan yang telah dilakukan. Kesejahteraan merupakan suatu ganjaran yang penting dan karenanya akan mempengaruhi motivasi kerja seseorang, sehingga dengan kesejahteraan yang baik akan mempunyai andil dalam upaya meningkatkan kinerja.

\section{Kerangka Pemikiran}

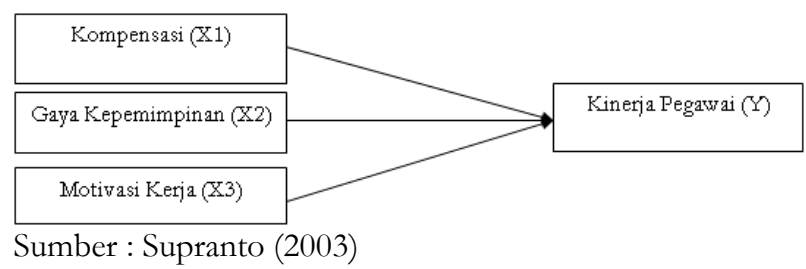

Hipotesis

Hipotesis adalah jawaban yang bersifat sementara terhadap permasalahan penelitian, sampai terbukti melalui data yang terkumpul Arikunto (2002). Berdasarkan uraian diatas, maka hipotesis yang yang di anjurkan dalam penelitian ini adalah:

1. Variabel kompensasi berpengaruh terhadap kinerja pegawai pada Badan Arsip Dan Perpustakaan Provinsi Aceh.

2. Variabel gaya kepemimpinan berpengaruh terhadap kinerja pegawai pada Badan Arsip Dan Perpustakaan Provinsi Aceh.

3. Variabel motivasi berpengaruh terhadap kinerja pegawai pada Badan Arsip Dan 
Perpustakaan Provinsi Aceh.

4. Variabel kompensasi, gaya kepemimpinan dan motivasi kerja berpengaruh signifikan terhadap kinerja pegawai pada Badan Arsip Dan Perpustakaan Provinsi Aceh.

\section{Metodologi Penelitian}

\section{Lokasi Dan Objek Penelitian}

Untuk mendapatkan data dan informasi dalam menyelesaikan karya akhir ini penulis mengadakan penelitian langsung pada Badan Arsip Dan Perpustakaan Provinsi Aceh yang beralokasi di jl. T. Nyak Arif Banda Aceh, dengan objek penelitian adalah kompensasi, gaya kepemimpinan, motivasi kerja dan kinerja pegawai subjek penelitian adalah pegawai Badan Arsip Dan Perpustakaan Provinsi Aceh.

\section{Populasi dan Penarikan Sampel}

Populasi adalah kumpulan individu dengan kualitas ciri-ciri yang telah ditetapkan. Menurut Sugiono (2007) populasi diartikan sebagai sekelompok elemen yang lengkap yang biasanya berupa orang, objek, atau kejadian dimana tertarik untuk mempelajarinya atau menjadi objek penelitiannya. Populasi dalam penelitian ini adalah pegawai Badan Arsip Dan Perpustakaan Provinsi Aceh yang berjumlah 181 orang, untuk mendapatkan sampel yang dapat menggambarkan dan mewakili dari populasi, maka dalam penentuan sampel penelitian ini menggunakan rumus slovin dalam umar sebagai berikut.

$$
\begin{array}{ll} 
& n=\frac{\mathrm{n}}{1+\mathrm{N}(\mathrm{e})^{2}} \\
\text { Dimana: } & \mathrm{n}=\text { jumlah sampel } \\
& \mathrm{N}=\text { jumlah populasi } \\
\mathrm{e}=\text { standar error } \\
n=\frac{181}{1+181(0.15)^{2}}=44,4=44
\end{array}
$$

dengan menggunakan rumus slovin sebesar $15 \%$ maka jumlah sampel minimum yang dapat diambil sebesar 44 orang

\section{Metode Pengumpulan Data}

Metode Pengumpulan data yang digunakan penulis adalah penelitian lapangan yang dilakukan dengan cara menyebarkan kuesioner yaitu sejumlah pertanyaan dalam bentuk daftar tertulis yang dieadarkan secara langsung kepada masing-masing pegawai. Kuesioner ini digunakan untuk mendapatkan informasi yang diperlukan dalam penelitian ini.

\section{Teknis Analisis Data}

Dari data yang terkumpul, baik dari data primer dan sekunder diolah dan dianalisa dengan menggunakan bantuan program SPSS peralatan analisis yang digunakan yaitu regresi linear berganda dengan pormulasi sebagai berikut:

$$
\mathrm{Y}=\mathrm{a}+\mathrm{b}_{1} \mathrm{x}_{1}+\mathrm{b}_{2} \mathrm{x}_{2}+\mathrm{b}_{3} \mathrm{x}_{3}+\mathrm{e}
$$

\section{Dimana}

$$
\begin{aligned}
& \mathrm{Y} \quad=\text { Kinerja pegawai } \\
& \text { a } \quad=\text { Konstanta } \\
& \mathrm{b}_{1} \quad=\text { Kofesiensi Regresi Variabel } \\
& \text { Kompensasi } \\
& \mathrm{b}_{2} \quad=\text { Koefisien Regresi Variabel Gaya } \\
& \text { Kepemimpinan } \\
& \mathrm{b}_{3} \quad=\text { Koefisien Regresi Variabel Motivasi } \\
& \mathrm{x}_{1} \quad=\text { Kompensasi } \\
& \mathrm{x}_{2} \quad=\text { Gaya Kepemimpinan } \\
& \mathrm{x}_{3}=\text { Motivasi Kerja } \\
& \text { e } \quad=\text { Error }
\end{aligned}
$$

\section{Uji Reliabilitas dan Validitas}

Uji reabilitas adalah suatu instrumen cukup dapat di percaya untuk di gunakan sebagai alat pengumpul data karena instrumen tersebut sudah baik Sugiono (2007). Instrumen yang baik tidak akan bersifat tendensius atau mengarahkan responden untuk memilih jawaban-jawaban tertentu. Instrumen yang sudah dapat dipercaya, yang reliabel akan menghasilkan data yang dapat dipercaya, apabila datanya benar-benar sesuai dengan kenyataannya, maka berapa kalipun diambil, tetap akan sama. Reabilitas menunjukkan pada tingkat keandalan (dapat dipercaya). Disini yang dapat dipercaya adalah datanya, bukan semata-mata instrumennya Sugiono (2007). Instrumen yang reliabel mengandung arti bahwa instrumen tersebut harus baik sehingga mampu mengungkap data yang bisa dipercaya. Alat untuk mengukur reabilitas adalah Alpha Cronbach Sugiono (2007:196). Suatu variabel dikatakan realibel, apabila:

Hasil $\alpha>0,06=$ reliabel

Hasil $\alpha<0,06=$ tidak reliabel 


\section{Hasil dan Pembahasan}

\section{Gambaran Umum Badan Arsip Dan Perpustakaan Provinsi Aceh}

Nanggroe Aceh Darussalam pertama didirikan tahun 1969 bernama Perpustakaan Negara yang berlokasi pada salah satu ruangan seluas $12 \mathrm{~m} 2$ di kantor Perwakilan Departemen Pendidikan dan Kebudayaan Daerah Istimewa Aceh dengan jumlah koleksi 80 ekseplar dan 2 orang pegawai. Berdasarkan surat keputusan Menteri Pendidikan dan Kebudayaan No. 8429/c/B.3/1979 berubah menjadi Perpustakaan Wilayah. Pada tahun 1989 terbit Kepres No. 11/1989 yang mengatur bahwa Perpustakaan Wilayah berubah nama menjadi Perpustakaan Daerah. Terbitnya Keppres No. 50 tahun 1997 tentang perubahan struktur organisasi Perpustakaan Nasional RI yang berdampak pula pada perubahan nama dari Perpustakaan Daerah menjadi Perpustakaan Nasional Provinsi D.I Aceh. Terbitnya Perda No. 39 tahun 2001 Perpustakaan Nasional Provinsi D.I Aceh telah menjadi salah satu lembaga daerah dengan nama Badan Perpustakaan Provinsi NAD. Terakhir UUD 11 tahun 2006 tentang pemerintah Aceh dan Qanun No. 5 tahun 2007 tentang perubahan struktur Organisasi Pemerintah Daerah maka Badan Perpustakaan Provinsi NAD digabung dengan Badan Arsip Provinsi NAD dengan nama Badan Arsip dan perpustakaan Provinsi NAD

\section{Uji Validitas}

Validitas adalah suatu ukuran yang menunjukkan tingkat-tingkat kevalidan suatu instrument. Sugiono (2007:168). Suatu intrumen yang valid atau sahih mempunyai validitas tinggi. Sebaliknya instrumen yang kurang valid berarti memiliki validitas rendah. Sebuah instrumen dikatakan valid apabila mampu mengukur apa yang diinginkan. Sebuah intrumen dikatakan valid apabila dapat mengungkapkan data dari variabel yang diteliti secara tepat. Tinggi rendahnya instrumen menunjukkan sejauh mana data yang terkumpul tidak menyimpang dari gambaran tentang variabel yang dimaksud. Alat untuk mengukur validitas adalah korelasi product moment dari pearson Sugiono, (2007:170). Suatu indikator dikatakan valid, apabila $\mathrm{n}=100$ dan $\alpha=0,05$, maka $\mathrm{r}$ tabel $=0,195$ dengan ketentuan Sugiono, (2007:184):

Hasil $r$ hitung $>r$ tabel $(0,195)=$ valid

Hasil $\mathrm{r}$ hitung $<\mathrm{r}$ tabel $(0,195)=$ tidak valid.

\section{Hasil Uji Asumsi Klasik}

Hasil Uji Normalitas

Uji normalitas yaitu pengujian apakah data yang di ambil telah mengikuti sebaran distribusi normal, yang bertujuan untuk membuat generalisasi hasil analisis dan sampel. Distribusi normal adalah distribusi yang relatif sederhana yang hanya melibatkan dua parameter (rata-rata dan varians), distribusi ini sangat di kenal dan sifat-sifat teoritisnya telah di pelajari secara luas dalam statistik matematika. Pengujian normalitas data dilakukan dengan melihat sebaran standarized residual pada kurva P-P plot. Bila standarized berada pada kisaran garis normal maka data mempunyai distribusi normal.

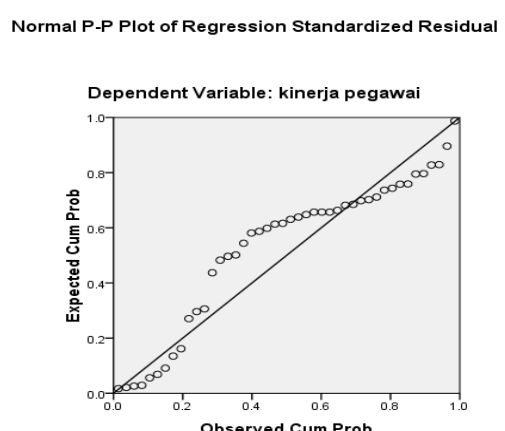

Gambar 1. Standarized Residual pada Kurva P-P Plot

Berdasarkan gambar diatas, dapat dilihat bahwa nilai plot PP terletak di sekitar garis diagonal. Dengan demikian, dapat di artikan bahwa data yang di gunakan dalam penelitian ini terdistribusi secara normal.

\section{Hasil Uji Heteroskedastisitas}

Uji heteroskedastistas bertujuan untuk menguji apakah dalam model regresi terjadi ketidaksamaan variance dari residual satu pengamatan ke pengamatan yang lain. Jika variance dari residual satu ke pengamatan yang lain tetap maka disebut homoskedastisitas dan jika berbeda disebut heteroskedastisitas. Model regresi yang baik adalah yang homoskedastisitas atau tidak terjadi heteroskedastisitas (Ghozoli, 2001). Deteksi ada tidaknya heteroskedastisitas dapat dilakukan dengan melihat ada tidaknya 
pola tertentu pada grafik scatterplot. Jika ada pola tertentu, seperti titik-titik yang ada membentuk pola tertentu yang teratur (bergelombang, melebar kemudian menyempit), maka mengidentifikasikan telah terjadi heteroskedastisitas. Jika tidak ada pola yang jelas, serta titik-titik menyebardi atas dan dibawah angka 0 pada sumbuY maka tidak terjadi heteroskedastisitas (Ghozoli, 2001). Hasil pengolahan data memperlihatkan grafik scatterplot seperti ditunjukkan dalam gambar berikut ini.

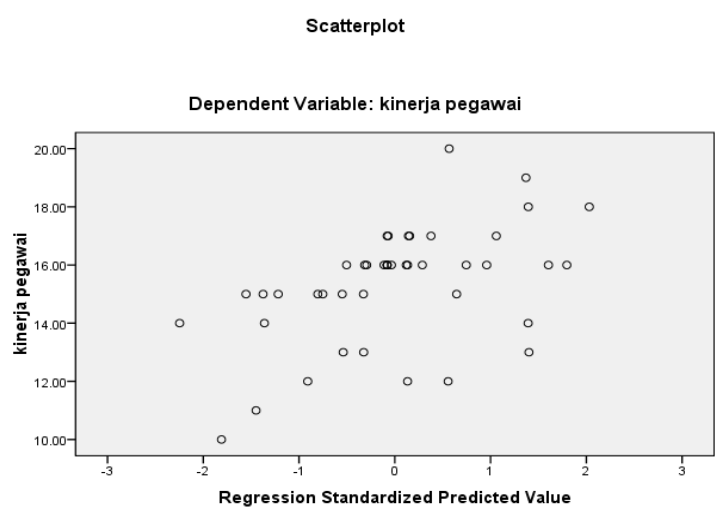

Gambar 2. Scatterplot Untuk Pengujian Heteroskedastisitas

Berdasarkan gambar di atas, terlihat bahwa grafik scatter plot tidak memiliki pola tertentu, dan titik-titik menyebar di atas dan di bawah angka 0 pada sumbu Y. Dengan demikian dapat di artikan tidak terjadi gejala heteroskesdastisitas.

\section{Pembahasan}

Untuk mengetahui pengaruh variabel bebas yaitu kompensasi (X1) gaya kepemimpinan (X2) dan motivasi kerja (X3) terhadap kinerja pegawai pada Badan Arsip Dan Perpustakaan Provinsi Aceh (Y). Pengaruh masing-masing variabel terikat secara terinci dapat dilihat pada tabel berikut ini:

Tabel 1. Bagian output SPSS yang memperlihatkan nilai koefisien regresi masingmasing variabel independent

\begin{tabular}{|c|c|c|c|c|c|c|c|c|}
\hline \multirow[b]{2}{*}{ Model } & & \multicolumn{2}{|c|}{\begin{tabular}{|c|} 
Unstandardized \\
Coefficients
\end{tabular}} & \multirow{2}{*}{\begin{tabular}{|c|}
$\begin{array}{c}\text { Standardized } \\
\text { Coefficients }\end{array}$ \\
Beta \\
\end{tabular}} & \multirow[b]{2}{*}{$\mathrm{T}$} & \multirow[b]{2}{*}{ Sig. } & \multicolumn{2}{|c|}{ Collinearity Statistics } \\
\hline & & B & Std. Error & & & & \begin{tabular}{|l|} 
Tolerance \\
\end{tabular} & $\mathrm{VIF}$ \\
\hline 1 & (Constant) & 8.343 & 2.499 & & 3.338 & .002 & & \\
\hline & kompensasi & .409 & .157 & .395 & 3.598 & .013 & .823 & 1.215 \\
\hline & gaya kepemimpinan & .321 & .161 & -.255 & 3.375 & .177 & .554 & 1.805 \\
\hline & motivasi kerja & .232 & .132 & .325 & 3.759 & .086 & .556 & 1.800 \\
\hline
\end{tabular}

Sumber: Data Primer (diolah) 2014
Berdasarkan hasil yang di tunjukan pada tabel di atas maka dapat di lihat suatu persamaan regresi linear berganda adalah sebagai berikut: $\mathrm{Y}=8,343+0,409 \mathrm{X} 1+0,321 \mathrm{X} 2+0,232 \mathrm{X} 3+\mathrm{e}$.

Dari persamaan regresi diatas, dapat di ketahui hasil penelitian bahwa Konstanta sebesar 8,343. Artinya jika kompensasi (X1) gaya kepemimpinan (X2) dan motivasi kerja (X3) di anggap konstan, maka besarnya kinerja pegawai Badan Arsip dan Perpustakaan Provinsi Aceh adalah sebesar 8,343 pada satuan skala likert. Koefisien regresi kompensasi (X1) sebesar 0,409. Artinya setiap 1 satuan perubahan (perbaikan karena tanda +) dalam variabel kompensasi, maka secara relatif akan mempengaruhi kinerja pegawai Badan Arsip dan Perpustakaan Provinsi Aceh sebesar 40,9\%, jadi kompensasi akan mempengaruhi kinerja pegawai Badan Arsip dan Perpustakaan Provinsi Aceh. Koefisien regresi gaya kepemimpinan (X2) sebesar 0,321. Artinya setiap 1 satuan perubahan (perbaikan, karena tanda +) dalam variabel gaya kepemimpinan, maka secara relatif akan mempengaruhi kinerja pegawai Badan Arsip dan Perpustakaan Provinsi Aceh sebesar $32.1 \%$ dengan demikian semakin tinggi pengaruh gaya kepemimpinan maka akan semakin mempengaruhi kinerja pegawai Badan Arsip dan Perpustakaan Provinsi Aceh.

Koefisien regresi motivasi kerja (X3) sebesar 0,232 . Artinya setiap 1 satuan perubahan (perbaikan, karena tanda + ) dalam variabel motivasi kerja, maka secara relatif akan mempengaruhi kinerja pegawai Badan Arsip dan Perpustakaan Provinsi Aceh sebesar 23.2\% dengan demikian semakin tinggi pengaruh motivasi kerja maka akan semakin mempengaruhi kinerja pegawai Badan Arsip dan Perpustakaan Provinsi Aceh.

Berdasarkan hasil analisa di atas, dapat di ketahui bahwa dari ketiga variabel yang di teliti, ternyata variabel kompensasi (X1) yang mempunyai pengaruh positif signifikan terhadap kinerja pegawai, dengan nilai koefisien sebesar 0,409 (40,9\%) pada Badan Arsip dan Perpustakaan Provinsi Aceh dan di ikuti oleh variabel gaya kepemimpinan (X2) dengan nilai koefisien sebesar 0,321 (32.1\%). Variabel motivasi kerja (X3) dengan nilai koefisien sebesar 0,232 $(23,2 \%)$. 


\section{Kesimpulan}

Berdasarkan hasil penelitian yang telah di lakukan, maka dapat di ambil beberapa kesimpulan sebagai berikut:

1. Nilai koefisien korelasi $(\mathrm{R})$ sebesar 0,892 menjelaskan terjadinya hubungan positif antara variabel terikat dengan variabel bebas dengan indeks korelasi 0,892 atau $89,2 \%$. Hubungan tersebut tergolong kuat karena melebihi 0,50 atau 50\%.

2. Koefisien determinasi (R2) $=0,522$, dimana dengan nilai tersebut terdapat hubungan antara variabel bebas dengan variabel terikat adalah sebesar $52,2 \%$ dan sisanya $52,2 \%$ dipengaruhi oleh variabel lainnya diluar model penelitian ini.

3. Hasil uji F (secara simultan) diperoleh $F_{\text {hitung }}$ sebesar 24.196, sedangkan $F_{\text {tabel }}$ pada tingkat signifikan $\alpha=5 \%$ adalah 3,225. Hal ini memperlihatkan bahwa Fhitung > Ftabel dengan signifikan 0.000. hasil perhitungan ini dapat diambil suatu kesimpulan bahwa menerima hipotesis alternatif dan menolak hipotesis nol, artinya bahwa variabel kompensasi (X1), gaya kepemimpinan (X2) dan motivasi kerja (X3) secara bersama-sama berpengaruh terhadap kinerja pegawai pada Badan Arsip dan Perpustakaan Provinsi Aceh. Menunjukkan bahwa secara keseluruhan responden menyatakan setuju terhadap indikator yang diteliti, dengan demikian variabel yang di teliti mempunyai pengaruh secara signifikan dalam mempengaruhi kinerja pegawai pada Badan Arsip dan Perpustakaan Provinsi Aceh

\section{Daftar Pustaka}

Akmal, Z., Lubis, A. R., \& Yunus, M. (2012). Pengaruh Kompensasi Terhadap Motivasi dan Disiplin Serta Dampaknya Pada Kinerja Pegawai Sekertariat Daerah Aceh Unsyiah. Fakultas Ekonomi Universitas Syiah Kuala Banda Aceh, Aceh, Indonesia.

Armstrong, Michael. (2005). Manajemen Sumber Daya Manusia. PT Elexmedia Komputindo. Jakarta.
Akny, A. B. (2014). Mewujudkan Good Governance melalui Reformasi Birokrasi di Bidang SDM Aparatur untuk Peningkatan Kesejahteraan Pegawai" dalam Jejaring Administrasi Publik, Th. Jejaring Administrasi Publik: Jurnal Ilmiah, Universitas Airlangga, 6(1), 416-427.

Antou, D. O. (2013). Gaya Kepemimpinan dan Budaya Organisasi Pengaruhnya Terhadap Kinerja Pegawai Kantor Kelurahan Malalayang I Manado. Jurnal EMBA: Jurnal Riset Ekonomi, Manajemen, Bisnis dan Akuntansi, 1(4).

As'ad, Moh, (2001), psikologi industri, Edisi keempat, Liberty, Yogyakarta.

Aulia Maya, U. (2020). Pengaruh promosi jabatan terhadap kepuasan kerja dan prestasi kerja pegawai dinas sosial kab. Brebes (Doctoral dissertation, Universitas Pancasakti Tegal).

Brahmasari, I. A., \& Suprayetno, A. (2008). Pengaruh motivasi kerja, kepemimpinan dan budaya organisasi terhadap kepuasan kerja karyawan serta dampaknya pada kinerja perusahaan (Studi kasus pada PT. Pei Hai International Wiratama Indonesia). Jurnal Manajemen dan kewirausahaan, 10(2), 124-135.

Dahlan, Siamat. (2004). Manajemen Lembaga Keuangan. FE Universitas Indonesia, Jakarta.

Firmandari, N. (2014). Pengaruh Kompensasi Terhadap Kinerja Karyawan Dengan Motivasi Kerja Sebagai Variabel Moderasi (Studi Pada Bank Syariah Mandiri Kantor Cabang Yogyakarta). Ekbisi, 9(1).

Ghozali, I. (2001). Aplikasi Analisis dengan program SPSS. Semarang: Badan Penerbit Universitas Diponegoro.

Handayati, R. (2016). Pengaruh Karakteristik Individu terhadap Kinerja Karyawan di Bank Jatim Cabang Lamongan (Suatu Studi pada Bank Jatim Cabang Lamongan). 
Handoko, Hani, T. (2002), manajemen personalia dalam sumber daya Manusia, Surabaya, insane cendekia

Hariandja, M. T. E. (2002). Manajemen sumber daya manusia. Grasindo.

Hasibuan, H. Malayu SP. (2004). Organisasi dan motivasi, Jakarta: Bumi Aksara.

Manullang, Marihot. (2003). Manajemen Sumber Daya Manusia. Edisi Pertama, Cetakan Pertama, Yogyakarta: BPFE.

Maria, A. (2012). Pengaruh Gaya Kepemimpinan, Pengembangan Sumber Daya Manusia Dan Disiplin Kerja Terhadap Kinerja Pegawai Sekretariat Dewan Perwakilan Rakyat Daerah Provinsi Sulawesi Tengah. Katalogis, 1(1).

Nitasari, R. A., \& Lataruva, E. (2012). Analisis pengaruh motivasi kerja terhadap kinerja karyawan dengan kepuasan kerja sebagai variabel intervening pada PT. Bank Central Asia tbk. cabang kudus (Doctoral dissertation, Fakultas Ekonomika dan Bisnis).

Nuraini, M. A., \& Siswanta, L. (2016). Pengaruh Gaya Kepemimpinan, Motivasi Kerja dan Disiplin Kerja terhadap Kinerja Karyawan STIKes Surya Global Yogyakarta. Universitas PGRI Yogyakarta.

Panggabean, S. Mutiara, (2002). Manajemen Sumber Daya Manusia. Jakarta: PT. Ghalia Indonesia.

REZA, R. A., \& Dirgantara, I. (2010). Pengaruh gaya kepemimpinan, motivasi dan disiplin kerja terhadap kinerja karyawan PT Sinar Santosa Perkasa Banjarnegara (Doctoral dissertation, Universitas Diponegoro).

Rivai, Veithzal. (2003). Manajemen Sumber Daya Manusia Untuk Perusahaan: dan Teori ke Praktik. Jakarta: PT. Raja Grafindo Persada.
Robbins, P. Stepen dan Coulter Mary. (2006). Perilaku Organisasi. Jakarta: Prenhalindo Edisi bahasa Indonesia.

Salutondok, Y., \& Soegoto, A. S. (2015). Pengaruh kepemimpinan, motivasi, kondisi kerja dan disiplin terhadap kinerja pegawai di kantor sekretariat DPRD Kota Sorong. Jurnal EMBA: Jurnal Riset Ekonomi, Manajemen, Bisnis dan Akuntansi, 3(3).

Samsudin, Sadili. M.M M.pd. (2006) Manajemen Sumber Daya Manusia. Jakarta: Pustaka Setia.

Sastrohadiwiryo, B. Siswanto, (2007). Manajemen Tenaga Kerja Indonesia: Pendekatan Administrasi dan Operasional. Jakarta: PT. Bumi Aksara

Sihotang, A, M.B.A. (2007). Manajemen Sumber Daya Manusia. Jakarta: PT. Pradnya Paramita.

Siswanto, B. (2002). Manajemen Tenaga Kerja Indonesia Pendekatan Administratif dan Operasional. Bumi Aksara, Bandung.

Sugiono, (2007), metode penelitian. Bandung: cetakan kedua, CV Alfabeta

Susanty, A., \& Baskoro, S. W. (2012). Pengaruh motivasi kerja dan gaya kepemimpinan terhadap disiplin kerja serta dampaknya pada kinerja karyawan (studi kasus pada pt. Pln (persero) apd semarang).J@ Ti Undip: Jurnal Teknik Industri, 7(2), 77-84.

Tampi, B. J. (2014). Pengaruh Gaya Kepemimpinan dan Motivasi terrhadap Kinerja karyawan pada PT. Bank Negara Indonesia, tbk (regional sales manado). Acta Diurna Komunikasi, 3(4).

Tampubolon, B. D. (2007). Analisis faktor gaya kepemimpinan dan faktor etos kerja terhadap kinerja pegawai pada organisasi yang telah menerapkan SNI 19-9001-2001. Jurnal standardisasi, 9(3), 106-115. 
Widayaningtyas, R. (2016). Pengaruh Disiplin Kerja dan Motivasi Kerja terhadap Kinerja Karyawan (Studi Pada PT. Macanan Jaya Cemerlang Klaten). Jurnal Manajemen Bisnis Indonesia (JMBI), 5(5), 527-537.

Widodo, U. (2006). Analisis Pengaruh Gaya Kepemimpinan dan Kepuasan Kerja Terhadap Kinerja Bawahan (Studi Empiris Pada Perguruan Tinggi Swasta di Kota Semarang). Fokus Ekonomi: Jurnal Ilmiah Ekonomi, 1(2).
Winardi, J, (2002). Motivasi dan permotivasian dalam manajemen. Jakarta:PT Raja Grafindo Persada.

Wursanto, 1g. (2005). Manajemen kepegawaian 1. Yogyakarta, kansius. 